\title{
The Impact Professors Have on College Students
}

\author{
Ami Rokach ${ }^{1}$ \\ ${ }^{1}$ York University, Canada; The Center for Academic Studies, Israel \\ Correspondence: Ami Rokach, Ph.D., York University, Canada; The Center for Academic Studies, Israel.
}

Received: October 22, 2016

Accepted: November 6, 2016

Online Published: November 11, 2016

doi:10.20849/ijsn.v1i1.80

URL: http://dx.doi.org/10.20849/ijsn.v1i1.80

\begin{abstract}
It is known that university students are significantly influenced by their professors. This review article surveys relevant research on the impact that professors actually have on students, which of their behaviors are important in creating that impact, and which behaviors professors may want to adopt, or enhance, in order to maximize the positive effect they have in their classes.
\end{abstract}

Keywords: professors, university students, motivation, caring, engagement, faculty- student interaction

"While in college, students may see their faculty members as the experts in their field of study and may value their opinion, knowledge, and expertise. Whereas previously they may have relied on parents or other family members for professional guidance, they now have another resource they can draw on, their faculty members... Hence, students who perceive their faculty members as being approachable and are able to engage them in conversation outside the immediate classroom could likely benefit career-wise. Students could possibly come away feeling more confident, motivated, and interested in performing well. Some faculty members may not realize the extent to which their informal interactions with students could potentially be associated with students' self-confidence, motivation, and performance"

(Komarraju, Musulkin and Bhattacharya, 2010; p. 340).

Uusiautti and Maatta (2013) indicated that ours is a time when increasing demands on efficient and productive higher education are placed, and student drop out is on the rise. They pose the question of how to make university students' academic experience such, that they succeed in their studies and complete their degrees, at least undergraduate ones. Professors, they argue, are front and center in that endeavour. The impact that professors have on students is firstly indicated by retention rates. Olson and Carter (2014) reported on a survey of 313 students in a 4-year university which found that, in general, students' retention rate was significantly increased when students perceived faculty as genuinely caring about them (see also Pascarella and Terenzini, 2005). Similarly, Muraskin, Lee, Wilner, and Swail (2004) found that caring, accessible and dedicated full time faculty were very important for retention.

Cruce, Wolniak, Seifer, and Pascarella (2006) suggested that good practices in education have a positive impact on students' development and engagement. Student-faculty interaction is a meaningful and important factor in students' academic and social success in university. Komarraju, Musulkin and Bhattacharya (2010) indicated a crucial ingredient in developing university students' academic self-concept as well as enhancing their motivation is the type and quality of student-teacher interactions. For instance, Faculty members who are interested in their students' academic progress, seem to make significant contributions in increasing their intellectual development (Cokley, 2000; Rosenthal et al, 2000). Those teacher-student interactions are particularly significant when they occur informally, increase students motivation, they remain engaged in class activities, and are actively involved in the learning process, and such an interaction has been identified as a primary agent of college culture, and has an important influence on the attitudes, interests, and values of college students (Pascarella and Terenzini, 2005; Thompson, 2001). Research found that student-faculty member relationship is more meaningful in predicting the social-emotional functioning of students than their academic performance (Decker, Dona, and Christenson, (2007). This implies that there is a support-seeking dimension in student-faculty relationships that can be carefully nurtured to shape positive outcomes for students. Informal interactions, outside of the classroom, or mentoring provided by faculty to students who transition into college, maybe even more important for their 
emotional and social wellbeing than peer support (Pascarella and Terinzini, 2005; Shore, 2003). Such student-faculty positive and nourishing interactions contribute to greater satisfaction with academic life, lesser likelihood of dropping out, and students feeling more intellectually driven (Hazler and Carney, 1993). Further, students are more likely to have a sense of purpose and competence in succeeding in college if their interactions with faculty are meaningful (Martin, 2000), they report greater learning and satisfaction with college and enhanced personal and intellectual development as a result of positive informal interactions with faculty members (Lamport, 1993). And inversely, students who perceive their faculty members as being less interested in them or in their learning seem to also report feeling discouraged and apathetic (Komarraju, Musulkin and Bhattacharya, 2010).

\section{Types of student-faculty interactions, and who seeks them}

Hagenauer and Volet (2014) have addressed what they termed TSR, meaning Teacher -Student Relationship and identified two main dimensions of this type of relationship: the affective dimension, which includes honesty, trust and respect and which describes the bond built between students and teachers forming the basis for secure and affective positively experienced relationships, and the support dimension, including respectful approach, trustworthiness, safe atmosphere, and fairness which describes the support that must be provided through TSR for students' success at university (see also Larsen, 2015).

Glass et al. (2015) indicated that an actual or possible change in one's relationships has the potential to evoke powerful emotions, which in the case of social inclusion may include such positive affects as calmness, anticipation, trust or joy (see Plutchik, 2011 for a review). We need to remind ourselves that the need to belong, the desire for frequent positive Interactions, and the wish to feel cared for by others is a fundamental human need (Baumeister and Leary, 1995), and thus students and faculty interactions are inevitable and the resultant personal connections that emerge through advisement and mentoring are highly valued by all (Light, 2001). Students respond, mainly, to implicit and nonverbal cues and are consequently more drawn to interact with faculty members whom they perceive to be sociable, intelligent, showing leadership, supportive, and objective (Babad, Avni-Babad, and Rosenthal, 2003; Furnham and Chamorro-Premuzic, 2005). Micari and Pasoz (2012) highlighted the importance of developing rapport and respect between faculty members and students, and asserted that it can be done in, both, verbal and nonverbal ways such as making eye contact, using humor and personal examples during lectures, and interacting with students outside of class. For instance, faculty members who allow their students to use their first name when they interact with them, are commonly perceived as sociable, intelligent, showing leadership, support, and objectivity (McDowell and Westman, 2005). Faculty may interact with students formally in class, informally out of class, or it could take on a more intense flavor in a tutorial style classroom, where a faculty member may meet with a small number of students for up to an hour. Such close, intense, interaction have been shown to enhance student learning and intellectual stimulation, with both students and faculty valuing the opportunity to get closer on an informal personal level (Smallwood, 2002).

Cox and Orehovec (2007) identified four major types of student-faculty interactions with the most important one, functional interactions which are basically academically related interactions occurring outside of the classroom. Next were personal interactions, dealing with personal issues, incidental contact which is expressed by occasional acknowledgement and greetings, and the fourth kind of interaction is disengagement which involves minimal student-faculty interaction in the classroom, and no interpersonal exchange.

Research indicates that mainly females seek interaction with faculty and usually report them to be positive (Hagedorn, Maxwell, Rodriguez, Hocevar, and Fillpot, 2000). Interestingly, Asian and South African students seem to have more positive perceptions of faculty with strict and even admonishing interaction and teaching styles (Evans and Fisher, 2000). Moreover, the more demanding those faculty members are, the more these two student populations seem to learn and benefit (Lundberg and Schreiner, 2004).

Komarraju, Musulkin and Bhattacharya (2010) indicated that the most meaningful and influential interaction is the informal one that students and faculty may have outside of the classroom. Students who perceive their faculty to be approachable, respectful, and available for frequent are more likely to report being confident of their academic skills and show greater motivation to study and develop, both intrinsically and extrinsically. These students are also more likely to find the learning process enjoyable and stimulating.

Uusiautti and Maatta (2013) found in their study that love, the deep caring of others which can be seen as a virtue or strength representing human kindness, compassion, and affection produces freedom, empowers and is vital to enhancing students' self-efficacy. When instructors exhibit love, forgiveness and trust in their relationship with students, it directly translates into satisfaction, commitment and loyalty (Prewitt, 2003; see also Rego et al., 2011). 


\section{Teacher's behaviors that can influence students}

"Research on caring demonstrates that when students perceive their teachers as caring, their grades and behavior are positively influenced" [Miller, 2008; Abstract]. Research indicated that faculty can positively influence students' self-efficacy, and instructors' characteristics are major players in developing students' interest (Krapp, 2002; Harackiewicz, Durik, Barron, Linnenbrink-Garcia and Tauer, 2008). Research demonstrates the significance of a teacher's interpersonal communication practices, such as immediacy, verbal and nonverbal communication (Song, Kim and Luo, 2016), self-disclosure (Cayanus, Martin and Goodboy, 2009), and other communicator's style such as humor (Micari and Pasoz, 2012) on learning experiences of students. Immediacy has been shown to particularly reduce social and psychological distance between people and it positively affects students' motivation to study. It was further found that an instructor's emphasis on developing interpersonal relationships through the use of immediacy behaviors operates as an essential factor in facilitating effective learning experiences (see Graham, West and Schaller, 1992; Stoltz and Bryant, 2013). The act of self-disclosure (SD), it was found, is a fundamental starting point in developing and maintaining interpersonal relationships (Derlega, Metts, Petronio, and Margulis, 1993). Self-disclosure increases linking and encourages intimacy (Collins and Miller, 1994). Teacher SD is defined as "conscious and deliberate disclosures about one's self, aspects of one's professional practice, world or personal views, personal history, and responses to ongoing classroom events" (Rasmussen and Mishna, 2008, p. 192). While self-disclosure is not an integral part of the curriculum, some teachers share their education/personal background, previous experiences, and opinions to clarify or illustrate class content more effectively (Cayanus and Martin, 2008; Hosek and Thompson, 2009). Komarraju, Musulkin and Bhattacharya (2010) found that when faculty members are approachable, respectful and available for frequent interaction outside of the classroom, students are more confident in their academic skills and report both intrinsic and extrinsic motivation.

Student engagement is essential to learning. The role of the college instructor in student engagement cannot be trivialized (Umbach and Wawrzynski, 2005). Student learning, retention and a quality undergraduate experience result from student engagement (Mantooth, 2011). Such quality undergraduate instruction builds on active learning, prompt feedback, collaboration and out of class contact with faculty. Humor can be used to engage students. Humor is effective at gaining students' attention and holding their interest (Deiter, 2000; Mantooth, 2011). Humor affects students physically and psychologically. Physically, it relaxes muscles, stimulates circulation, improves respiration, relieves the body's stress, empowers the immune system and lowers pulse rate and blood pressure (Berk, 2002). Humor also affects students psychologically in that it decreases anxiety, stress and tension, improves self-esteem, and increases curiosity, comprehension (Garner, 2006; Philaretou, 2006; Stambor 2006). Humor also increases instructor immediacy, which is the perceived distance between an instructor and the students. Humor creates a classroom that is open to student participation, facilitates learning, and builds cohesion among the students (Burbach \& Babbitt, 1993; Garner, 2006). "Humor has been shown to stimulate creativity, create positive learning environments, help students retain and comprehend information, encourage class attendance, engage students in the learning process, and facilitate a connection between the instructor and the student" (Mantooth, 2011; p. 6).

\section{Faculty positive impact on students: Caring behaviors}

Teven and McCroskey (1997) found that educators' behaviors significantly impact students' behavioral patterns. The more students feel that their instructors care about them, the more likely they are to care about the class and consequently attend more regularly. Some tips on how faculty can increase their positive impact on students were provided by Olson and Carter (2014) who highlighted the importance of faculty's caring approach on students. In order to convey caring, they recommended adopting a stance of always serving students and indicating that it is actually a pleasure to do so. Making culturally-considerate eye contact, smiling warmly, and inviting the student to share his concerns. Providing undivided attention in the moment is quite powerful in demonstrating our caring for the individual. Providing positive feedback to students, indicates not only faculty's caring but may also enhance their ability to think and write critically. One way professors can instill confidence in their students, is to make a special effort to encourage creativity and freethinking by being open to new ideas and providing constructive criticism, rather than criticism that would deflate a student's confidence.

Fostering Openness and Accessibility - even the manner in which the faculty's office is set up can convey caring. Sitting close to the student, rather than with a large desk between them, conveys openness and accessibility, rather than distance and closeness.

Unconditional positive regard - Just like in psychotherapy, acceptance of the student and his/her performance is of utmost importance. And so, the faculty need to approach students with the belief that each of them has the 
competence to study, produce written work, and complete the degree. The student will perceive it and feel encouraged and empowered by it.

Faculty who trust that their students are capable, set high but achievable expectations. Caring for students includes careful consideration of desired learning outcomes and development of manageable academic tasks that gradually move the students toward successful completion of those learning outcomes.

Faculty can have a significant impact on students' confidence level. Instilling in students the ability to think independently, critically and creatively, and solve methodological and applied problems, need themselves to be open to new ideas, encourage independent thinking, and provide positive feedback.

Acting as an appropriate adult model - faculty members can serve as appropriate models for their students in becoming responsible people, who display pro social behavior. That can be done by modeling to students of professional boundaries, ethical responsibilities and honesty.

Keeping response times short - students need, and contact their instructors, mostly via e-mail or phone calls. Getting back to students within 24 hours indicates that their concern is valued, and that the instructor made an effort to find time, and respond to them quickly. Similarly, providing rapid evaluative feedback is important for the same reasons, i.e. that faculty appreciates the work that the student invested in his work, and knows that the student is anxiously waiting for the comments and the grade that the faculty has the power to assign.

To conclude, Olson and Carter (2014) point out that "Call it 'accessibility,' 'approachability,' 'respect,' 'enthusiasm', and so forth, but the bottom line is, "What students still want most is us" (Groth, 2007, p. 41). Moreover, students need "us" to display unconditional positive regard and the multitude of other behaviors one categorizes as "caring." If we are to make a difference, and promote retention and success, students need to know that we care about them, both inside and outside of the classroom" (p. 8).

\section{References}

Babad, E., Avni-Babad D. A., \& Rosenthal, R. (2003). Teachers' brief nonverbal behaviors in defined instructional situations can predict students' evaluations. Journal of Educational Psychology, 95(3), 553-562. http://dx.doi.org/10.1037/0022-0663.95.3.553

Baumeister, R. F., \& Leary, M. R. (1995). The need to belong: Desire for interpersonal attachments as a fundamental human motivation. Psychological Bulletin, 117(3), 497-529. http://dx.doi.org/10.1037/0033-2909.117.3.497

Berk, R.A. (1996). Student ratings of 10 strategies for using humor in college teaching. Journal on Excellence in College Teaching, 7(3), 71-92.

Burbach, H.J., \& Babbitt, C.E. (1993, Jan. - March). An exploration of the social functions of humor among college students in wheelchairs. Journal of Rehabilitation, 6-9.

Cayanus, J. L., \& Martin, M. M. (2008). Teacher self-disclosure: amount, relevance, and negativity. Communication Quarterly, 56, 325-341. http://dx.doi.org/10.1080/01463370802241492

Cayanus, J. L., Martin, M. M., \& Goodboy, A. K. (2009). The relation between teacher self-disclosure and student motives to communicate. Communication Research Reports, 26, 105-113. http://dx.doi.org/10.1080/08824090902861523

Cokley, K. (2000). Perceived faculty encouragement and its influence on college students. Journal of College Student Development, 41(3), 348-352.

Collins, N., \& Miller, L. (1994). Self-disclosure and liking: a meta-analytic review. Psychological Bulletin, 116(3), 457-475. http://dx.doi.org/10.1037/0033-2909.116.3.457

Cox, B. E., \& Orehovec, E. (2007). Faculty-student interaction outside the classroom: A typology from a residential college. The Review of Higher Education, 30(4), 343-362. http://dx.doi.org/10.1353/rhe.2007.0033

Cruce, T., G. C. Wolniak, T. A. Seifert, \& E. T. Pascarella. (2006). Impacts of good practices on cognitive development, learning orientations, and graduate degree plans during the first year of college. Journal of College Student Development, 47(4), 2006, 365-383. http://dx.doi.org/10.1353/csd.2006.0042

Decker, M. D., Dona P. D., \& Christenson S. L. (2007). Behaviorally at risk African American students: The importance of student-teacher relationships for student outcomes. Journal of School Psychology, 45, 83-109. http://dx.doi.org/10.1016/j.jsp.2006.09.004 
Deiter, R. (2000). The use of humor as a teaching tool in the college classroom. NACATA Journal, 20-28.

Derlega, V. J., Metts, S., Petronio, S., \& Margulis, S. T. (1993). Self-disclosure. Newbury Park, CA: Sage.

Evans, H., \& Fisher, D. (2000). Cultural differences in students' perceptions of science teachers' interpersonal behavior. Australian Science Teachers Journal, 46(2), 9-18.

Furnham, A., \& Chamorro-Premuzic, T. (2005). Individual differences in students' preferences for lecturers' personalities. Journal of Individual Differences, 26(4), 176-184. http://dx.doi.org/10.1027/1614-0001.26.4.176

Garner, R.L. (2003). Which came first, the chicken or the egg? A foul metaphor for teaching. Radical Pedagogy, 5(2). Retrieved from http://radicalpedagogy.icaap.org/content/issue5_2/04_garner.html

Garner, R.L. (2006). Humor in pedagogy: How ha-ha can lead to aha! College Teaching, 54(1), 177-180. http://dx.doi.org/10.3200/CTCH.54.1.177-180

Glass, C.R., Kociolek, E., Wongtrirat, R., Lynch, R.J., \& Summer, C. (2015). Uneven experiences: The impact of student-faculty interactions on international students' sense of belonging. Journal of International Students, 5(4), 353-367.

Graham, E. E., West, R., \& Schaller, K. A. (1992). The association between the relational teaching approach and teacher job satisfaction. Communication Reports, 5(1), 11-22. http://dx.doi.org/10.1080/08934219209367539

Groth, M. (2007). Smart classrooms cannot replace remarkable professors. Thought and Action, 23(4), 39-45.

Hagedorn, L., Maxwell, W., Rodriquez, P., Hocevar, D., \& Fillpot, J. (2000). Peer and student- faculty relations in community colleges. Community College Journal of Research and Practice, 24(7), 587-599. http://dx.doi.org/10.1080/10668920050139730

Hagenauer, G., \& Volet, S. E. (2014) Teacher-student relationship at university: an important yet under-researched field, Oxford Review of Education, 40(3), 370-388. http://dx.doi.org/10.1080/03054985.2014.921613

Harakiewicz, J.M., Durik, A.M., Barron, K.E., Linnenbrink-Garcia, L., \& Tauer, J.M. (2008). The role of achievement goals in the development of interest: Reciprocal relations between achievement goals, interest,

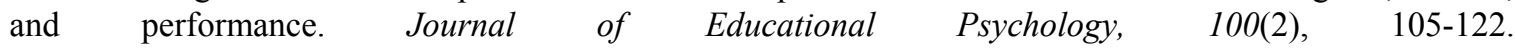
http://dx.doi.org/10.1037/0022-0663.100.1.105

Hazler, R., \& Carney, J. (1993). Student-faculty interactions: An underemphasized dimension of counselor education. Counselor Education \& Supervision, 33(2), 80-89. http://dx.doi.org/10.1002/j.1556-6978.1993.tb00271.x

Hosek, A. M., \& Thompson, J. (2009). Communication privacy management and college instruction: exploring the rules and boundaries that frame instructor private disclosure. Communication Education, 58(3), 327-349. http://dx.doi.org/10.1080/03634520902777585

Komarraju, M. Musulkin, S., \& Bhattacharya, G. (2010). Role of Student-Faculty Interactions in Developing College Students' Academic Self-Concept, Motivation, and Achievement. Journal of College Student Development, 51(3), 332-342. http://dx.doi.org/10.1353/csd.0.0137

Krapp, A. (2002). Structural and dynamic aspects of interest development: Theoretical considerations from an $\begin{array}{lllll}\text { ontogenetic perspective. Learning and } & \text { Instruction, }\end{array}$ http://dx.doi.org/10.1016/S0959-4752(01)00011-1

Lamport, M. A. (1993). Student-faculty informal interaction and the effect on college student outcomes: A review of the literature. Adolescence, 28(112), 971-990.

Larsen, A. S. (2015). Who Cares? Developing a Pedagogy of Caring in Higher Education (Doctoral Dissertation). Retrieved From ProQuest.

Light, R. J. (2001). Making the most of college: Students speak their minds. Cambridge, MA: Harvard University Press.

Lundberg, C. A., \& Schreiner, L. A. (2004). Quality and frequency of interaction of faculty- student interaction as predictors of learning: An analysis of student race/ethnicity. Journal of College Student Development, 45(5), 549-565. http://dx.doi.org/10.1353/csd.2004.0061

Mantooth, J. D. (2011). The effects of professor humor on college students' attention and retention (Order No. 
AAI3430615). Available from PsycINFO. Retrieved from http://ezproxy.library.yorku.ca/login?url=http://search.proquest.com/docview/884680130?accountid=15182

Martin, L. M. (2000). The relationship of college experiences to psychosocial outcomes in students. Journal of College Student Development, 41(3), 292-301.

McDowell, J. E., \& Westman, A. S. (2005). Exploring the use of first name to address faculty members in graduate programs. College Student Journal, 39(2), 353-356.

Micari, M., \& Pazos P. (2012). Connecting to the Professor: Impact of the Student-Faculty Relationship in a $\begin{array}{lllll}\text { Highly Challenging } \quad \text { Course, } & \text { College }\end{array}$ http://dx.doi.org/10.1080/87567555.2011.627576

Miller, R. M. (2008). The Influence of Teachers Caring Behavior on High School Students Behavior and Grades. Seton Hall University Dissertations and Theses (ETDs). Paper 1633.

Muraskin, L., Lee, J., Wilner, A., \& Swail, W.S. (2004, December). Raising the graduation rates of low-income college students. Washington, DC: The Pell Institute for the Study of Opportunity in Higher Education.

Olson, J.N., \& Carter, J.A. (2014). Caring and the college professor. Focus on Colleges, Universities, and Schools, 8(1), 1-9.

Pascarella, E.T., \& Terenzini, P.T. (2005). How college affects students, volume 2, a third decade of research. San Francisco, CA: Jossey-Bass.

Philareatou, A. G. (2006). Learning and laughing about gender and sexuality through humor: The woody allen case. The Journal of Men's Studies, 14(2), 133-144. http://dx.doi.org/10.3149/jms.1402.133

Plutchik, R. (2011). The nature of emotions. American Scientist, 89(4), 344-350.

Prewitt, V. (2003). Leadership development for learning organizations. Leadership \& Organization Development Journal, 24(2), 58-61. http://dx.doi.org/10.1108/01437730310463242

Rasmussen, B. M., \& Mishna, F. (2008). A fine balance: instructor self-disclosure in the classroom. Journal of Teaching in Social Work, 28, 191-207. http://dx.doi.org/10.1080/08841230802179274

Rego, A., Ribeiro, N., Pina, M., \& Jesuino, J. C. (2011). How happiness mediates the organizational virtuousness and affective commitment relationship. Journal of Business Research, 64(5), 524- 532. http://dx.doi.org/10.1016/j.jbusres.2010.04.009

Rosenthal, G., Folse, E. J., Allerman, N. W., Boudreaux, D., Soper, B., \& Von Bergen, C. (2000). The one-to-one survey: Traditional versus non-traditional student satisfaction with professors during one-to-one contacts. College Student Journal, 34(6), 315-321.

Shore, C. (2003, May). Recognizing high quality mentoring of undergraduate researchers. Paper presented at MPA/CTUP, Chicago, Illinois.

Smallwood, S. (2002). Me and my professor: Oxford style tutorials. Chronicle of Higher Education, 43, A16-A18.

Smith, B. (2015) The Evolution of My Rapport: One Professor's Journey to Building Successful Instructor/Student Relationships. College Teaching, 63(2), 35-36. http://dx.doi.org/10.1080/87567555.2014.999023

Song, H., Kim, J., \& Luo W. Teacher-student relationship in online classes: A role of teacher self-disclosure. Computers in Human Behavior, 54, 436-443. http://dx.doi.org/10.1016/j.chb.2015.07.037

Stambor, Z. (2006). How laughing leads to learning. Monitor on Psychology, 37(6), 62- 66.

Stoltz, M., \& Bryant, K. (2013). Does the amount and relevance of teacher self-disclosure affect student cognitive learning? In Proceedings at the annual convention of the Georgia communication association.

Teven, J. J., \& McCroskey, J. C. (1997). The relationship of perceived teacher caring with student learning and teacher evaluation. Communication Education, 46, 1-9. http://dx.doi.org/10.1080/03634529709379069

Thompson, M. D. (2001). Informal student-faculty interaction: Its relationship to educational gains in science and mathematics among community college students. Community College Review, 29(1), 35-58. http://dx.doi.org/10.1177/009155210102900103

Umbach, P., \& Wawrzynski, M. (2005). Faculty do matter: The role of college faculty in student learning and engagement. Research in Higher Education, 46(2), 153-184. http://dx.doi.org/10.1007/s11162-004-1598-1 
Uusiautti, S., \& Maatta, K. (2013). Enhancing university students' study success through caring leadership. European Scientific Journal, 9(19).

\section{Copyrights}

Copyright for this article is retained by the author(s), with first publication rights granted to the journal.

This is an open-access article distributed under the terms and conditions of the Creative Commons Attribution license (http://creativecommons.org/licenses/by/4.0/). 